\title{
New liverworts from the Peruvian Andes. I. Colura ochyrana and Drepanolejeunea halinae (Lejeuneaceae, Marchantiophyta)
}

\begin{abstract}
New liverworts from the Peruvian Andes. I. Colura ochyrana and Drepanolejeunea halinae (Lejeuneaceae, Marchantiophyta). - Acta Mus. Siles. Sci. Natur., 68: 37-44, 2019.

Abstract: During an intensive ecological and biodiversity research project in the eastern Andes of central Peru large number of bryophytes were collected including many species new to Peru and a few even to science. The present paper describes two new species of Lejeuneaceae, Colura ochyrana and Drepanolejeunea halinae, which seem to be endemic to the Andes.
\end{abstract}

Key words: Andes, endemism, Lejeuneaceae, new species, Peru.

\section{Introduction}

The exploration of the liverworts in Peru until the end of last century is well summarized by Menzel (1984), starting with the collecting activities of Eduard Friedrich Poeppig as early as 1829-1830 (Frahm \& Eggers 1995) and culminating in the long South-American collecting journey of Richard Spruce in the mid-19th century, of which he spent 6 months in Perú. This resulted in his monumental opus (Spruce 1884, 1885), followed by Ernst Heinrich Georg Ule and August Weberbauer. During the last century bryological research in Peru was carried out by Alexander William Evans, Fortinato Luciano Herrera, Eberhard and Pirkko Hegewald, and by the 5-membered Bryotrop Expedition organized by Jan-Peter Frahm and Wolfgang Frey during August-September 1982 (e.g., Frey 1987) in northern Peru focusing on floristics, zonation and ecology along an elevation transect from 500-3500 m. Japanese researchers studied south Peruvian cryptogams (Inoue, 1987) and Kürschner and Parolly (1998) described the epiphytic bryophyte communities and their life strategies and life forms along the Bryotrop transect. In the meantime important monographs were published from genera widespread in the Andes. Then the first guide to the bryophytes of Tropical America was written by Gradstein et al. (2001), helping orientation among the numerous neotropical genera. Local illustrated floras of Brazil (Gradstein \& da Costa, 2003) and of central French Guiana (Gradstein \& Ilkiu-Borges, 2009) were published, with many species occurring also in Peru but sure the most important work for the identification of Andean liverwort species will be the hepatic flora of Columbia and Ecuador by Gradstein (submitted).

During the present century, Peruvian universities also extended their interest towards bryophytes. Yasmin Alexandra Opisso Meija and Steven P. Churchill (Universidad San Marcos, Lima and Bolivian Program of the Missouri Botanical Garden, USM) published the first bryophyte records from the Yanachaga-Chemillén National Park, including 13 species new to Peru (Opisso \& Churcill, 2008). Bryan Espinoza-Prieto (also from Universidad San Marcos, Lima) started to deal with Peruvian Frullania (Atwood et al., 2018). Prof. James G. Graham (Herbario Forestal, Universidad Nacional Agraria La Molina, Lima, Perú, MOL and Field Museum, Chicago, F), during his botanical, ecological and landscape studies collected large amount of bryophytes in a remote, botanically less known area in the Amazonian outpost of the eastern Andes, in the Cordillera el Sira. The specimens were sorted out by Margaux Fischer (Field Museum). Tamás Pócs (Eszterházy University, Eger, EGR) started to identify the liverworts of them. As a result, a joint paper was published (Graham et al., 2016) 
recording 178 species including 38 new to Perú, with observations on their climatic, edaphic and microhabitat heterogeneity.

These results suggested further investigation in the area and a joint project was initiated called "Bryological investigation of the Central Jungle (Selva Central) Region of Peru". The first collecting expedition took place between 13 and 27 May 2016, with the support of the Field Museum, Chicago (F), Herbario Forestal in Molina (MOL), Herbario Selva Central in Oxapampa (HOXA), the Eszterházy Károly University, Eger (EGR) and the Hungarian Academy of Sciences. There were 6 participants (Jim Graham, Lars Söderström, Matt von Konrat, Carl Rothfels, Juan Larraín and Tamás Pócs), including experts of liverworts, mosses, ferns and phanerogams. The team visited and collected in Reserva Puyu Sacha (Dept. Junín), Sho'llet Municipial Reserve of Oxapampa, Cañon Huancabamba in the Yanachaga-Chemillén Nat. Park, Santa Barbara and at Catarata Rio Tigre, Mesapata (Dept. Pasco). The collection resulted in approximately 1200 bryophyte specimens and 373 ferns and fern allies, most collected in duplicates enough to be distributed between Field Museum, HOXA and the herbaria of the collector or identifier.

In 2017 a similar expedition was organized by James G. Graham, from 20 July to 5 August (Pócs 2017), parallel to a course to train Peruvian bryologists, during 20-25 July. The participants of the expedition included James G. Graham, Margaux Fischer, Judit Havasi and Tamás Pócs. The locations visited were La Florida Forest Reserves in Distr. Chontabamba near Oxapampa (together with the course), Santuario Nacional Pampa Hermosa (Prov. Chanchamayo, distr. San Ramon) where much time was spent, the limestone area around Huapapo Cave NW of Palcamayo, and finally the dry puna at the altiplano near Condorcocha and San Piedro de Casas, Dept. Junin, prov. Tama.

\section{Methods}

From the rich material collected by J.G. Graham and by the two expeditions, liverworts are being identified by T. Pócs (EGR) except for members of genus Plagiochila, which will be determined by Margaux Fischer (F). The collected specimens will be deposited Herbario Forestal (MOL), Univ. Nacional Agraria La Molina, Lima Perú, in the Herbarium of Eszterházy University, Eger, Hungary (EGR) and in the Herbarium of Field Museum, Chicago (F). The ecological and phytogeographical evaluation of all taxa is carried out by J. G. Graham (MOL and F). A great part of Lejeuneaceae and Lepidoziaceae are already identified by the author, of which a few turned out to be new to science. Two of these new taxa are described below to the honor of prof. Ryszard Ochyra and of Prof. Halina Bednarek-Ochyra.

\section{Results}

Colura ochyrana Pócs, sp. nov. (sect. Colura)

Figs. 1-10

DIAGNOSIS: Unique among members of sect. Colura by its very large, conical sac and by its long, papillose perianth horns. The conical sac reminds of some members of sect. Harmophyllum, but the five horns of perianth and the 2 triangular basal median cells of valve indicate its proper placement in sect. Colura.

TYPE: PERU, Junín, Prov. Chanchamayo, Distr. San Ramón, Bosque de Puyu Sacha, bosque montano con Weinmannia, Podocarpus, Ceroxylum, Cinchona, Cecropia, Saraouya, Lauraceae y Myrtaceae, sendero a la cascada. $11^{\circ} 05^{\prime} 40^{\prime \prime S} ; 7^{\circ} 25^{\prime} 34^{\prime \prime W}$. Alt. 2190-2200 m. Sobre hojas. Coll. T. Pócs \& M. von Konrat No. 1601/BU, Juan Larraín No. 39741/AA, accompanied by 38 other epiphyllous liverwort species (Holotype HOXA, Isotype EGR, F).

DESCRIPTION: Plants medium-sized, pale green, epiphyllous, forming irregular colonies of 2-7 mm, shoots 2$3 \mathrm{~mm}$ long, stems 30-50 $\mu \mathrm{m}$ thick. Leaves erect, 1-1.5 mm long, lobe 160- $240 \mu \mathrm{m}$ wide with auriculate base. Lobe cells irregular or isodiametric 5- or 6-gonal, 20-40 $\mu \mathrm{m}$ diameter with evenly thin walls. Lobule lanceolate, prolonged in a cone-shaped, long, acute sac, occupying 2/5-1/2 length of the leaf and usually ending in two parallel cells. Both the lobe and lobule cells are mamillose on the outer surface, each cell bulging into a hemispheric mamilla (visible only in wet state). Valve (Fig. 9) $80 \times 62 \mu \mathrm{m}$, with 13-14 hyaline marginal and with 10 median cells, of which the two basal are triangular in shape. Underleaves asymmetric, widely V-shaped, the lobes spreading from the stem at an angle of $60-80^{\circ}$. One of the underleaf lobes about 200 , the other one $160 \mu \mathrm{m}$ long, 2-3 cells wide in the lower half, 1 cell wide in the upper half, usually ending in an ovate, rounded cell. Rhizoids colorless, unicellular, with coral-like branching. Perichaetial leaves obtuse, with crenulate apex. Perianth urn- 
shaped, 1000-1120 $\mu \mathrm{m}$ long and 330-420 $\mu \mathrm{m}$ wide, without the 5 acute horns. Beak not emerging, one cell high, formed by somewhat elongated cells (Fig. 7). Perianth cells quadrate, 20-25 $\mu \mathrm{m}$ large, mamillose similarly to the lobe and lobule cells, but cells at the tip of horns and around the beak more bulging than the rest. Androecia and vegetative reproduction unknown.

ETYMOLOGY: the new species is named in the honor of Prof. Ryszard Ochyra, the author's friend since 40 years and expert of the mosses of Eurasia, Africa and the Subantarctic and Antarctic regions.

RANGE: PERU. Known only from the type locality (Fig. 21).

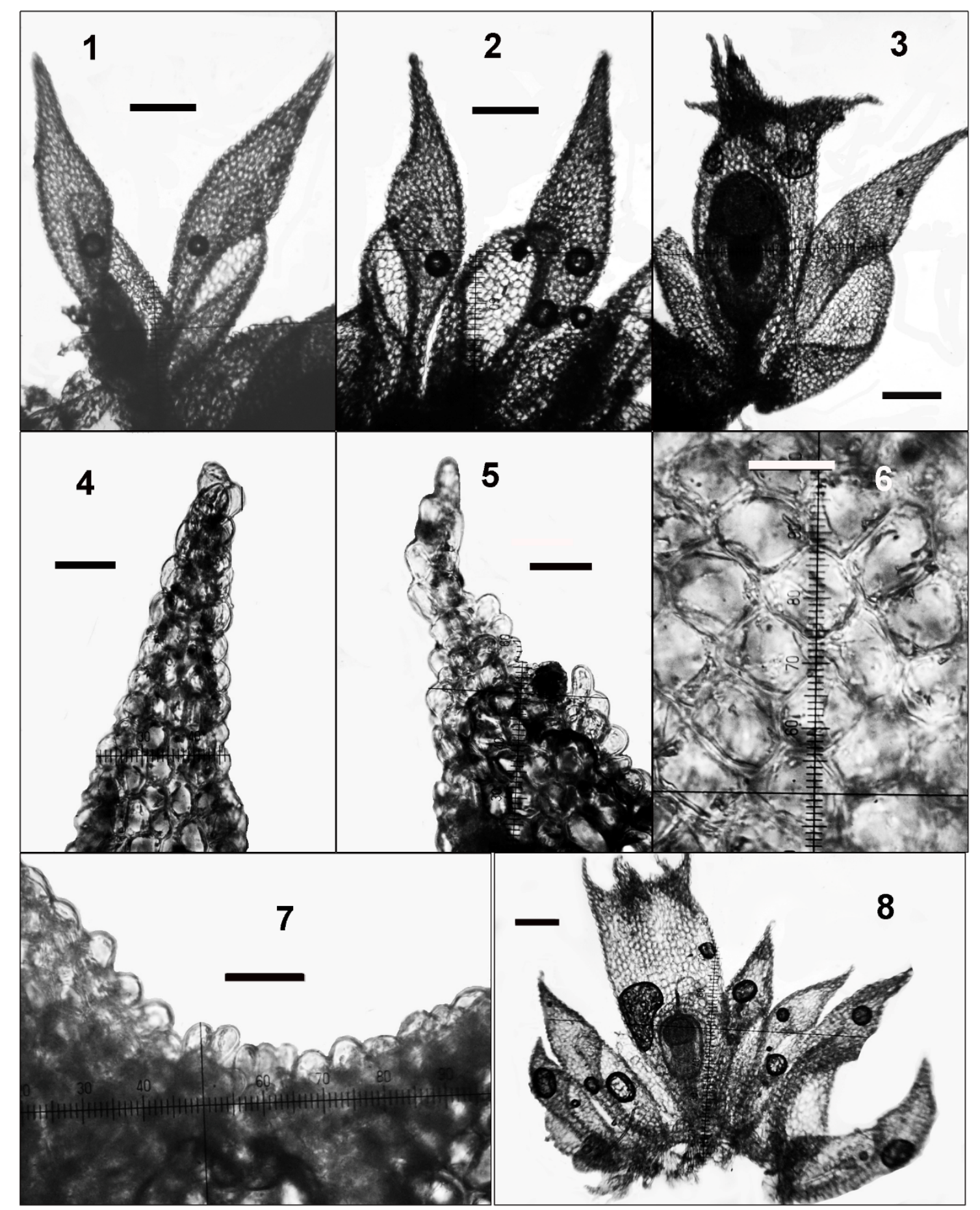

Figs 1-8: Colura ochyrana Pócs, sp. nov. 1-2 - leaves, ventral view. Scale bar $200 \mu \mathrm{m}$. 3 - Perianth. Scale bar $100 \mu \mathrm{m} .4$ - Apex of sac. Scale bar $50 \mu \mathrm{m} .5$ - Apex of perianth horn. Scale bar $50 \mu \mathrm{m} .6$ - Cells of perianth wall. Scale bar $25 \mu \mathrm{m} .7$ - Perianth mout with immersewd beak. Scale bar $25 \mu \mathrm{m}$. 8 - Habit of a shoot with perianth. Scale bar $200 \mu \mathrm{m}$. 


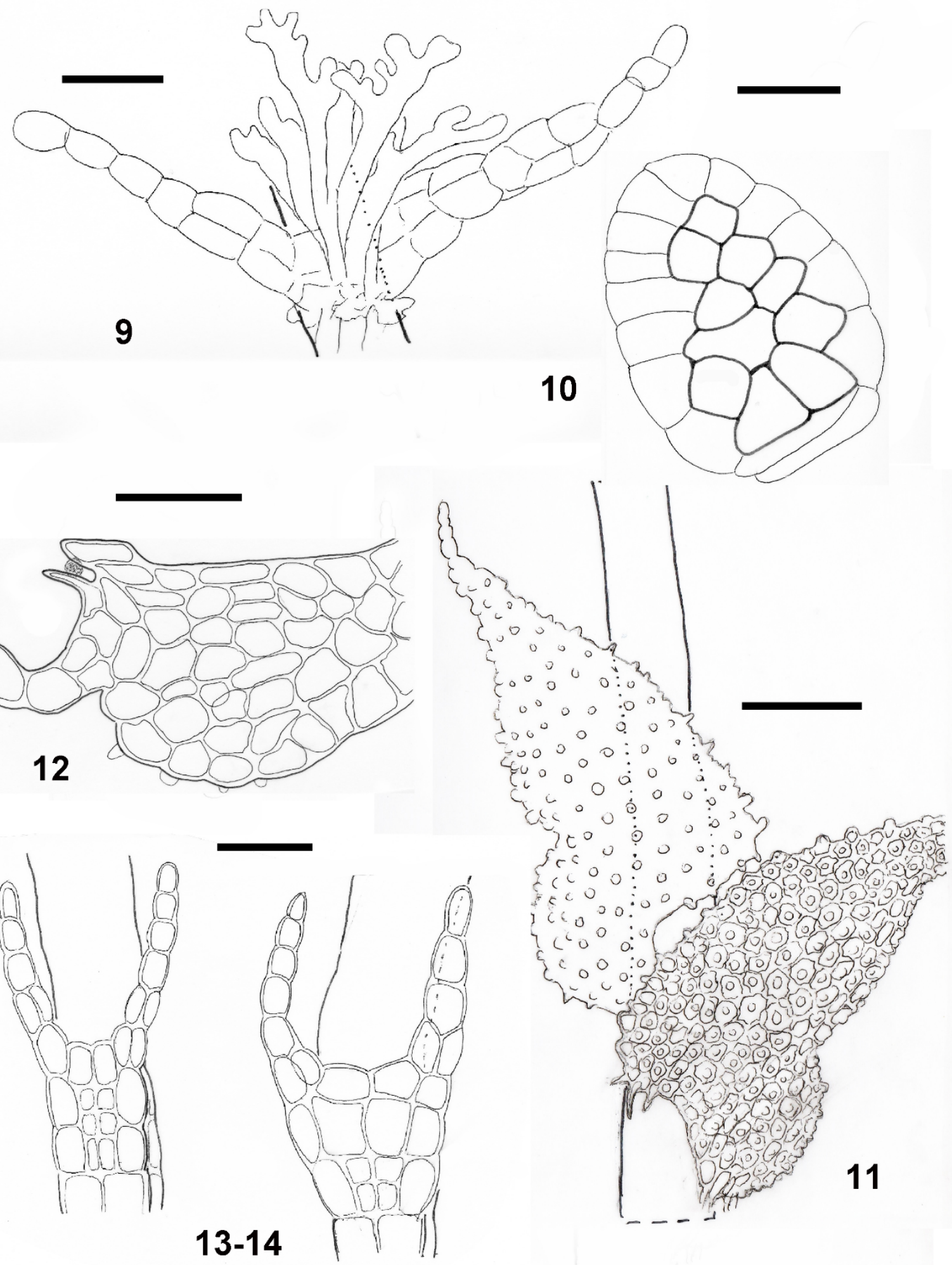

Figs 9-10: Colura ochyrana Pócs, sp. nov. 9 - Underleaf and rhizoids. Scale bar $25 \mu \mathrm{m}$. 10 - Valve. Scale bar 25 $\mu \mathrm{m}$. 11-14: Drepanolejeunea halinae Pócs, sp. nov. 11 - Dorsal view of leaves, with their shoulder covering the stem. Scale bar $100 \mu \mathrm{m} .12$ - Lobule, ventral view. Scale bar $50 \mu \mathrm{m}$. 13-14: Underleaves. Scale bar $25 \mu \mathrm{m}$. 
DIAGNOSIS: By its strongly papillose leaves with an auriculate and spinose shoulder, which overlaps on the dorsal side of the stem and by the two parallel lobule teeth with a narrow slit in which the hyaline papilla is situated, this species seems quite isolated among Neotropical Drepanolejeunea species. It can be classified in the sect. Auritae R.M. Schust., where it resembles the Andean D. cutervoensis (Loitl.) Grolle (= D. navicularis Steph.) in the lobule teeth but differs clearly in having 1-cell wide underleaf lobes. In its lobule teeth and leaf papillosity the species also resembles Drepanolejeunea submuricata R.M.Schust. ex L.Söderstr. et A.Hagborg (sect. Anoplanthae R.M. Schust.) from Dominica but clearly differs from the latter by the strongly dentate lobe margin and by the lack of the two big basal ocelli in a row, typical for this section.

TYPE: PERU, Ucayali, Prov. Coronel Portillo, Dist. Iparia, Alturas del cerro Ariapo, Reserva Comunal el Sira, Cabecera de la cuenca (oeste) del Rio Ariapo, afluente del Rio Ucayali. 9 28' 29" S; 74 35' 04" W. Alt. 2000$2050 \mathrm{~m}$. Bosque enano, con abundante luz solar. Crece por suelo en campo abierto. Coll. J.G. Graham No. 5407 p.p., in cushion of Syzygiella rubricaulis (Nees) Steph. and Bazzania roraimensis (Steph.) Fulford (Holotype F, Isotypes MOL and EGR, in form of microslide).

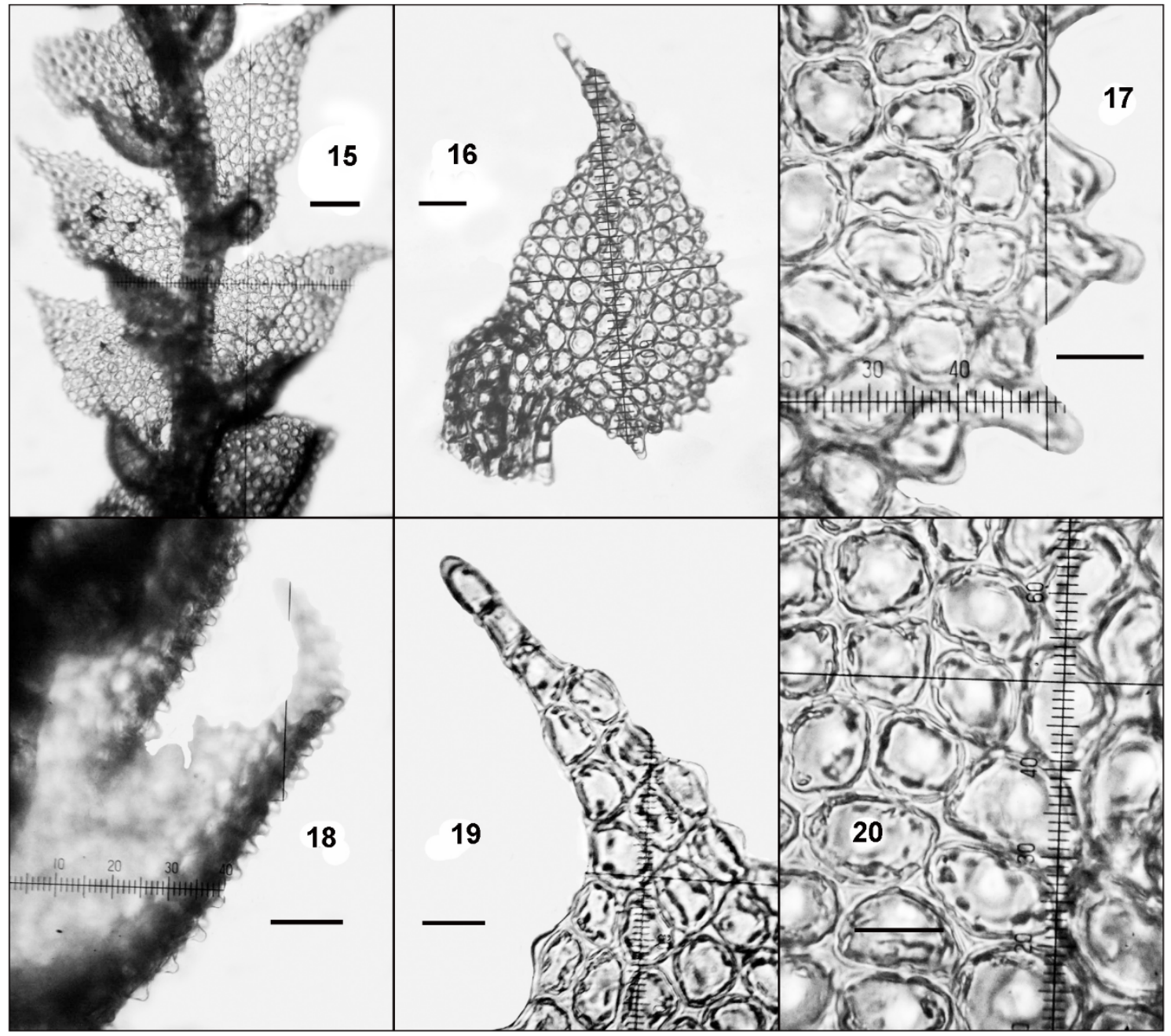

Figs 15-20: Drepanolejeunea halinae Pócs, sp. nov. 15 - Habit, ventral view. Scale bar 100 m. 16 - Leaf, dorsal view. Scale bar $50 \mu \mathrm{m} .17$ - Dorsal lobe margin. Scale bar $20 \mu \mathrm{m}$. 18 - Dorsal leaf papillae. Scale bar $50 \mu \mathrm{m}$. 19 - Lobe apex. Scale bar $20 \mu \mathrm{m} . \mathbf{2 0}$ - Median lobe cells. Scale bar $20 \mu \mathrm{m}$.

DESCRIPTION: Plants very small, yellowish brown in dry state, creeping in a cushion of other bryophytes. Shoots 6-8 mm long and 0.4-0.7 mm wide, stems with hyalodermis, 50-60 $\mu \mathrm{m}$ thick, irregularly branched. Leaves spreading at an angle of $40-60^{\circ}$ to the stem, about $500 \mu \mathrm{m}$ long, lobe $200-250 \mu \mathrm{m}$ wide with dentate margin, falcate, acute apex ending in a row of $2-3$ cells. Antical lobe base auriculate and spinose, dorsally overlapping the stem. Lobe cells isodiametric or slightly elongate, 20-30 $\mu \mathrm{m}$ in diameter, cell walls with concave trigones and intermediate thickenings. Each cell of the lobe and the keel is tipped dorsally by one large papilla. Ocelli on 
the herbarium specimens could not be observed. Lobule ovate, prolonged in a wide angle to the ventral and in a very sharp angle to the dorsal lobe margin. There are two equally long lobule teeth with a narrow slit in between, holding the hyaline papilla. The ventral lobule cells are smooth, without papillae. Underleaves $90-100 \mu \mathrm{m}$ long, U-shaped with a base as wide as the stem, composed of 6-10 large and a few smaller, median cells. The almost parallel, forward directed underleaf lobes consist of 6-8 cells in one row except at their base. Gametoecia not known. Vegetative reproduction by branch propagules.

ETYMOLOGY: This peculiar Drepanolejeunea species is named in the honor of Prof. Halina Bednarek-Ochyra, renowned monographer of rhacomitrioid mosses and skilled bryophyte illustrator.

RANGE: PERU. Known only from the type locality. It seems to be a characteristic species of mossy elfin woodlands.

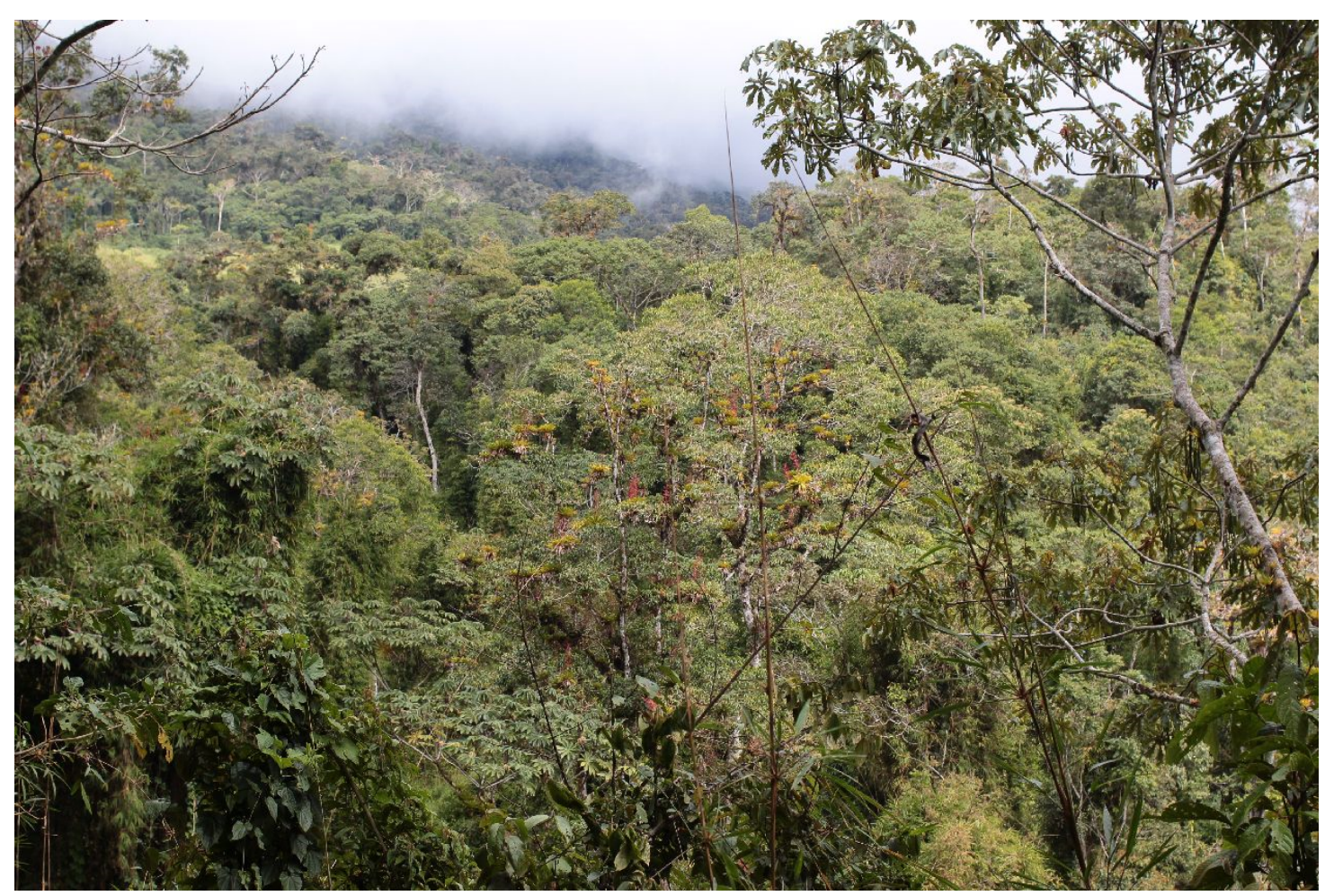

Fig 21: Peru, type locality of Colura ochyrana Pócs.

\section{Discussion}

The genus Colura is represented by fewer species in the New World tropics than in other continents: some 15 species in America, 20 in Africa and more than 40 in Asia, Australasia and the Pacific (Jovet-Ast 1953, 1954, Pócs 1996, Grolle \& Zhu 2002). Therefore it has a great significance that a new species of the genus was found in Perú. The new species seems to be identical to the plant illustrated in the "Guide to the Brophytes of Tropical America" (Gradstein et al. 2001: 177, Fig. A-E; figures also published in Gradstein \& da Costa 2003) under the name $C$. tortifolia (Nees \& Mont.) Steph., originally described from French Guiana (JovetAst 1953, Gradstein \& Ilkiu-Borges 2009) and widespread in tropical America in lowland rainforest areas. The latter species sharply differs from $C$. ochyrana by having 3 short perianth wings instead of 5 horns and a valve with 1-2 subquadrate median basal cells (not triangular), and belongs in Colura sect. Harmophyllum. Although the origin of the plant illustrated by Gradstein et al. (2001) was not indicated, it suggest that $C$. ochyrana is more widespread in the Neotropics and that further records of the new species may be hidden in herbaria under the name $C$. tortifolia. A revision of the neotropical collections of $C$. tortifolia is recommended. Possibly, C. ochyrana is restricted to the montane forest belt. 
The tiny Drepanolejeuna species are common in montane habitats of the Neotropics and usually occur on different substrates, as bark, decaying wood and on living leaves, on rocks or on peaty soil. Obviously the Andes are one of their diversity center with at least 35 species (Bischler 1964, 1968, 1968a, Schuster 1996). Although several attempts were made to produce an infrageneric classification for the genus (Herzog, 1930, Bischler 1964, Grolle, 1976, Schuster, 1996, Grolle et al. 2000), this subject remains problematic until it can be unequivocally established which characters are results of homoplasy. Leaf and lobule shape, dentition, underleaf and perianth characters are in many cases randomly distributed, not forming parallel groups. Only future molecular investigation can clarify the real infrageneric relationships in Drepanolejeunea.

Acknowledgments: The author acknowledges with thanks the opportunity to study the rich liverwort material collected by Prof. James G. Graham and the other members of the two expeditions. He expresses his thanks for the financial and logistical support of Field Museum, Chicago (F), namely to Dr. Matt von Konrat, Head of Botanical Collections, Bryophytes and Pteridophytes; to Herbario Forestal in Molina (MOL), Herbario Selva Central in Oxapampa (HOXA), the Eszterházy Károly University, Eger (EGR) and the Hungarian Academy of Sciences. He is also very grateful for the technical help in sorting, selecting and incorporating the herbarium material to Anna Balla and Margaux Fischer (F), Dr. Andrea Sass-Gyarmati and Réka Kádár (EGR). Finally he thanks the many supporting amendment and corrections made by Prof. Stephan Robbert Gradstein (PC), who was kind to review the manuscript.

\section{References}

Atwood J.J., Espinoza-Prieto B., Gradstein S.R. (2018): A new species of Frullania (Marchantiophyta: Frullaniaceae) from the Andes of Peru, and a range extension for $F$. holostipula to Bolivia. - Bryophyte diversity and evolution 40(2): 68-78.

Bischler H. (1964): Le genre Drepanolejeunea Stephani en Amérique Centrale et Méridionale. - Revue Bryologique et Lichénologique 33: 15-179.

- (1968): Le genre Drepanolejeunea Stephani en Amérique Centrale et Méridionale. Part II. - Revue Bryologique et Lichénologique 35: 95-134.

- (1968a): Le genre Drepanolejeunea Stephani en Amérique Centrale et Méridionale. - Revue Bryologique et Lichénologique 35: 135-137

Frahm J-P. \& Eggers J. (1995): Lexikon deutschsprachiger Bryologen. Edited by the authors, Norderstedt, 672 pp.

Frey W. [ed.] (1987): Moosflora und -vegetation in Regenwäldern NO-Perus. Ergebnisse der Bryotrop-Expedition nach Peru 1982. - Beihefte zur Nova Hedwigia 88: 1-158.

Gradstein S.R., Churchill S.R. \& Salazar-Allen N. (2001): Guide to the Bryophytes of Tropical America. - Memoirs of the NewYork Botanical Garden 86: 1-577.

Gradstein S.R. \& Pinheiro da Costa D. (2003): The Hepaticae and Anthocerotae of Brazil. - Memoirs of the NewYork Botanical Garden 87: 1-318.

Gradstein S.R. \& Ilkiu-B orges A.L. (2009): Guide to the plants of Central French Guiana, Part 4. Liverworts and Hornworts. - Memoirs of the NewYork Botanical Garden 76(4): I-IV + 1-140.

Graham J.G., Fischer M. \& Pócs T. (2016): Bryoflora and landscapes of the eastern Andes of central Peru: I. Liverworts of the El Sira Communal Reserve. - Acta Biologica Plantarum Agriensis 4: 3-60.

Grolle R (1976): Drepanolejeunea subg. Kolpolejeunea - eine neue Untergattung aus der Paläeotropis. - Journal of the Hattori Botanical Laboratory 40: 191-216.

Grolle R. \& Zhu R.-L. (2000): A study of Drepanolejeunea subg. Rhaphidolejeunea (Herzog) Grolle \& R.L.Zhu, stat. nov. (Hepaticae, Lejeuneaceae) in China with notes on its species elsewhere. - Nova Hedwigia 70 (3/4): 373-396.

- (2002): On Macrocolura and the subdivision of Colura (Lejeuneaceae, Hepaticae). - Journal of the Hattori Botanical Laboratory 92: 181-190.

Inoue H. [ed.] (1987): Studies on Cryptogams in Southern Peru. - Tokai University Press, Tokyo, 192 pp.

Jovet-Ast S. (1953): Le genre Colura, Hépatiques, Lejeuneacees, Diplasiae. - Revue Bryologique et Lichenologique 22(2/3): 206-312.

- (1954): Le genre Colura, Hépatiques, Lejeuneacees, Diplasiae (supplement). - Revue Bryologique et Lichenologique $23(1 / 2): 1-22$. 
Kürschner H. \& Parolly G. (1998). Stammepiphytische Moosgesellschaften am Andenostabhang und im Amazonas-Tiefland von Nord-Peru. - Nova Hedwigia 66(1-2): 1-87.

Menzel M. (1984): Katalog der Lebermoose von Peru, 1. - Willdenowia 14: 473-523.

Opisso J.M. \& Churchill S.P. (2008): Bryophytes from the environs of Yanachaga-Chemillén National Park, Department of Pasco, Peru. - The Bryologist 111: 310-317.

Pócs T. (1996): Epiphyllous liverwort diversity at worldwide level and its threat and conservation. - Annales Inst. Bot. Univ. Nac. Autón. Mexico, Ser. Bot. 67: 109-127.

- (2017) Curso-taller sobre hepáticas tropicales. - The Bryological Times 145 (Nov. 2017): 11.

Schuster RM (1996) Studies on Lejeuneaceae II. Neotropical taxa of Drepanolejeunea (Spr.) Schiffn. - Nova Hedwigia $62(1 / 2): 1-46$.

Spruce R. (1884) Hepaticae amazonicae et andinae. I. - Transactions and Proceedings of the Botanical Society of Edinburgh 15: 1-308.

- (1885): Hepaticae amazonicae et andinae. II. - Transactions and Proceedings of the Botanical Society of Edinburgh 15: 309-588.

Author's address: Tamás Pócs, Dept. of Botany, Institute of Biology, Eszterházy Károly University, Eger, Pf. 43, H-3301, Hungary.

E-mail: colura@upcmail.hu 